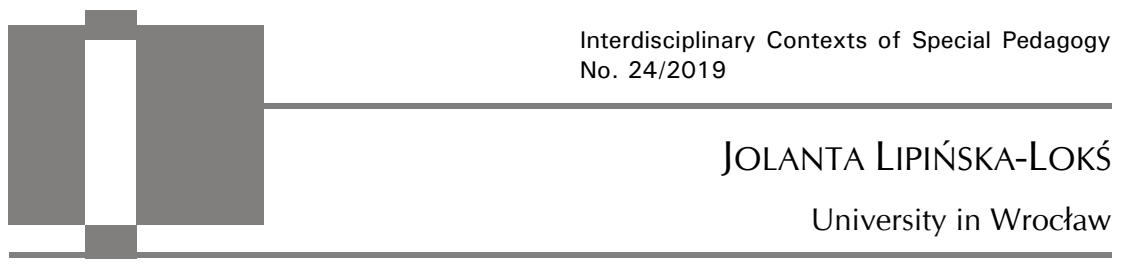

\title{
Love experienced by persons with disabilities
}

\begin{abstract}
Jolanta Lipińska-Lokś, Love experienced by persons with disabilities. Interdisciplinary Contexts of Special Pedagogy, no. 24, Poznań 2019. Pp. 27-49. Adam Mickiewicz University Press. ISSN 2300-391X. DOI: https://doi.org/10.14746/ ikps.2019.24.02
\end{abstract}

Humans as social beings feel natural attraction to being with other people, i.e. to establishing and maintaining relationships. Affiliations, such as friendship or love, significantly influence their development from the earliest years of life, either enriching or disturbing the quality of their functioning. Therefore, those who due to their health status or another life situation are marked by otherness, must be prepared to endure hardships. Consequently, persons with disabilities experience failures in their interpersonal contacts. They are often devoid of the opportunity to have a good friend or to experience true love, which may exacerbate their already difficult situation, often triggered within a family setting, where there was no acceptance and/or insufficient quality of parental love. All human beings, children in particular, need closeness and affection. Only then do they develop properly, experience happiness, see the meaning of their lives, feel loved and are able to reciprocate that love. Experiencing a disability or being a parent of a child with a disability may make love more difficult, perhaps even impossible. However, the desire for love can be so strong that it will manage to overcome all obstacles. Unfortunately, it may as well make life a grey existence filled with loneliness and suffering.

KEY WORDS: disability, person with disability, affiliations, love 


\section{Foreword}

The concept of love, although popularly known and used, is a major challenge for anyone who wishes to define love. Intuitively, we understand very well what love means, but the problem is to define it. Leksykon psychologii [Lexicon of Psychology] says that the concept of love has many meanings and "most typically, it means strong affection to a specific person (object), accompanied by pursuit of that person's proximity"1. Stownik psychologii [Dictionary of Psychology] defines love as a "permanent feeling to a person accompanied by a desire to be with that person and care for that person's happiness and satisfaction" 2 . Meanwhile, Stownik wspótczesnego jezyka polskiego [Dictionary of Contemporary Polish Language] defines love as "a deep feeling for another persons, usually combined with the desire to constantly be with that person and bestow happiness on that person (...); a strong attachment to someone; willingness to dedicate oneself to and serve someone"3. Love manifests itself through care and tenderness and a feeling of great emotional bond with another person, who occupies a central place in the life of the person who loves. A person who loves is ready to give up "many personal matters, and sometimes even love for the object of their love" 4 . Problems with definition are probably due to the fact that there exist many different types of love and that "it concerns various states, attitudes, experiences and feelings" 5 , as well as persons. One must mention here motherly, brotherly, friendly, marital love (love between partners), love of oneself, of God or of the home-

${ }^{1}$ L. Bakiera, Ż. Stelter, Leksykon psychologii rozwoju człowieka, Dyfin SA, Warszawa 2011, p. 263.

2 A.S. Reber, Stownik psychologii, Wydawnictwo Naukowe SCHOLAR, Warszawa 2002, p. 372.

3 B. Dunaj, Stownik wspótczesnego jezzyka polskiego, Wydawnictwo WILGA, Warszawa 1996, p. 524.

${ }^{4}$ W. Szewczuk, Stownik psychologiczny, Wiedza Powszechna, Warszawa 1979, p. 147.

${ }^{5}$ L. Bakiera, Ż. Stelter, Leksykon psychologii rozwoju człowieka, Dyfin SA, Warszawa 2011, p. 263. 
land. There is also unselfish, platonic, sensual or romantic love, or the recently mentioned (by Elizabeth Hurlock, as a stage in the emotional development of adolescents) childish or puppyish love. Love may be lasting, mutual, sincere and real ${ }^{6}$.

There are many perceptions of love, but it is always regarded as very important. According to Erik Erikson, love is a developmental force (basic virtue) that stimulates the development of intimacy and helps build closeness without fear of losing one's own identity. For Abraham Maslow, love is the basic need in healthy human development. Elizabeth Hurlock, too, when presenting various types of love (childish, puppyish, romantic), believes them to be an indicator of the proper emotional development of adolescents ${ }^{7}$. Saint Paul, in his First Epistle to the Corinthians, says: "And now these three remain: faith, hope and love. But the greatest of these is love" Wisława Szymborska, in her poem "Tale on the Love of the Fatherland" speaks very beautifully of this kind of love: "(...) one can live without that love (...). It is possible to not love you - and live, but it is not possible to be fruitful"9. Lack of such love not only impoverishes a human and his or her life. Not experiencing love makes one's life to be only dull existence.

\section{Object, method and technique of research, and the respondent group}

It is natural for every human being to feel the need for affiliative relationships. Special role is attributed to love, which can determine

${ }^{6}$ Ibidem, p. 263-265; cf B. Dunaj, Stownik wspótczesnego jezyka polskiego, Wydawnictwo WILGA, Warszawa 1996, p. 524.

${ }^{7}$ Cf L. Bakiera, Ż. Stelter, Leksykon psychologii rozwoju człowieka, Dyfin SA, Warszawa 2011, p. 264.

${ }^{8}$ Św. Paweł, Pierwszy List do Koryntian, 1 Kor 13, Pismo Święte Starego i Nowego Testamentu, Komisja Przekładu Pisma Świętego (przekład), Brytyjskie i Zagraniczne Towarzystwo Biblijne, Warszawa 1977, p. 1237-1238.

9 W. Szymborska, Gawęeda o mitości Ziemi Ojczystej, [in:] Strofy o Ojczyźnie. Antologia, S.R. Dobrowolski (wybór), Państwowe Wydawnictwo „Iskry”, p. 233. 
the high quality of life and a feeling of happiness. For this important reason, the object of diagnosis are the opinions of persons with disabilities about the significance of love in their life and their experiencing of that feeling.

The respondent group consisted in total of 40 persons (of which 12 persons took part in the author's individual research on affiliative relationships in human life). The respondent group was diversified in terms of gender, age, marital status, place of residence, family, education and professional situation. All the respondents were with disabilities, but the type and degree of those disabilities differed (motor, sensory - visual, hearing disability, somatic disability - chronic diseases: epilepsy, diabetes, mild intellectual disability, mental - schizophrenia, hysterical neurosis, anxieties, depressions, multiple disabilities).

Love in the lives of persons with disabilities was analyzed on the basis of the opinions of the respondents on their current close relations with other people and their former experiences in this area (experiencing parental love, the love of a partner).

The research was qualitative in nature. The individual case study and interview with interview survey methods were used.

The results presented herein constitute only a selected element of the entire research on the quality of life of persons with disabilities conducted over a number of years. The author's individual research is supplemented with the results of research conducted by students ${ }^{10}$ attending the MA seminar given by the author of this study.

10 The paper includes results of research conducted by D. Kaczmarek, B. Kałużna, N. Kotapska, K. Marzęda as part of the MA seminar (the MA dissertations were defended in 2014 and 2015). The dissertations constitute source material and the authors consented to the use of the results of their research and their dissertations. Certain fragments (research results, quotations of the respondents) were also used in articles published in academic journals, e.g. in: J. Lipińska-Lokś, Zachowania ryzykowne młodzieży z niepetnosprawnościa, „Interdyscyplinarne Konteksty Pedagogiki Specjalnej” 2014, no. 7, p. 9-25; J. Lipińska-Lokś, Koleżeństwo i przyjaźń w doświadczeniach osób z niepetnosprawnościa, „Niepełnosprawność. Dyskursy Pedagogiki 


\section{Experiencing parental love by persons with disabilities}

The love of a parent to a child may be taken for granted, the same as a child's great desire to experience the parent's love. Reciprocity of feelings in the child - parent relation is a natural consequence of the bond that unites them. Love makes parents feel fulfilled and children - important and safe. Love becomes particularly important in difficult situations that go beyond the popular standards. One of such situations is undoubtedly the disability of a child. Parents and children experience love and are capable to give and take love. Most typically, such love is defined as "difficult and often painful, because experienced in solitude, with a sense of opposition to social attitudes (...). A specific combination of love, pain, suffering, fear and despair"11. Nonetheless, such love seems to be the most important thing in the life of parents and their children. It enables them to overcome difficulties and makes their lives meaningful.

Interestingly, it may take many shapes, but always the welfare of the child, the way the parents understand it, lies at its core. Małgorzata Kościelska identifies 11 shades of love. It is worth presenting them here and considering the consequences of a given type of love for the development of a child and the functioning of the family system. Love can be:

a) symbiotic, taken for granted in the earliest period of a child's life, slowly, as a child develops, becomes a problem both for the mother (who, in most cases, does not realize it) and for the child, since, as Małgorzata Kościelska claims, "this kind of a relationship poses a threat to the development of the child's individual $\mathrm{Me}^{\prime \prime} 12$;

Specjalnej" 2015, no. 20, p. 57-69; B. Kałużna, J. Lipińska-Lokś, Aspiracje i plany życiowe (nie)pełnosprawnych zielonogórzanek, "Niepełnosprawność - zagadnienia, problemy, rozwiązania" 2016, no. 1, p. 60-89.

${ }^{11}$ M. Kościelska, Oblicza upośledzenia, Wydawnictwo Naukowe PWN, Warszawa 1995, p. 57.

12 Ibidem, p. 59. 
b) committing and compensating love, that tries at all costs to make it up for the child that he or she is disabled and protect the child from the dangers of the world. Parents who have that kind of love are on the brink of a breakdown because they are constantly on the watch-out and control the child and the situations that he or she experiences. Consequently, the child becomes passive and socially isolated and the live with a sense of commitment ${ }^{13}$;

c) shy, when a parent is at emotional crossroads, on the one hand, being authentically attached to a child and caring for the child as parents do but, on the other hand, identifying him or herself with "the social values that are against disability" 14 . Such parent, loving his or her child, is at the same time ashamed of having such a child. The child sees that he or she is being avoided by the parent and, in most cases, does not understand why, as he or she has done nothing wrong - he or she is just disabled. With time, the child may start to think like the parent and become ashamed of his or her disability;

d)from a distance, when, despite of declarations of loving a child, a parent does not cope with having a child with disability. Being with a child is a torture for a parent, a proof of failed parenthood. Such parents try to balance their negative emotions by escaping into work, earning money to provide for the family, which is socially accepted and, at the same time, does away with the remorse felt by the parent who loves his or her child but preferably without having to have too much contact with him or her ${ }^{15}$. A child feels emotionally rejected by the absent parent;

e) the go-ahead, pro-active love of a parent addressed to a child and his or her like. A parent creates conditions for a child to develop as best as possible and be present in the social space.

13 Ibidem, p. 60.

14 Ibidem, p. 60.

15 Cf ibidem, p. 61-62. 
Go-ahead parents, on the one hand, have a sense of mission: to raise social awareness about persons with disabilities and fight for their being accepted but, on the other hand, in their combat, they manifest many claims, believing that the injustice must be compensated. The children of go-ahead parents are familiar with the world around them but also, "in such contacts, they are often, perhaps unnecessarily, hurt and humiliated and they involuntarily become a tool for manipulation"16;

f) love striving for normality at all costs, which, however, has little to do with normal life for a child. It is an effort to "make a child normal" by treating the child as if he or she did not experience any limitations associated with disability. It is a certain defense mechanism for the parents who will perhaps never come to terms with the otherness of their child, or will even negate his or her developmental problems. A child, who experiences such parental love will never be able to meet their expectations, will try to be normal, but, not being able to overcome his or her limitations, will feel less valuable and guilty of the unhappiness of the parents;

g) rationalized love, trying to explain to oneself and to others the disability of a child. Such love is a duty and a task, since there exist more or less reasonable causes for the disability in the family. A child who experiences such love will be surrounded by care, since his or her parents fulfil without any reservations the tasks bestowed on them by God or fate. Unfortunately, in such task-based approach to a child, his or her actual child often go unnoticed ${ }^{17}$;

h) not reciprocated love, often very painful for the parents, takes place when contact with a child is much limited due to the nature of the impairment. A parent expects a child to reciprocate his or her feelings, but not receiving any signs of love from

16 Ibidem, p. 61.

17 Ibidem, p. 62. 
the child, experiences negative emotions and his or her motivation to act for the child may be reduced, which in turn may intensify a sense of injustice and guilt for the child's condition. A child (in this case, typically autistic or with severe intellectual disability) lives in his or her own world and experiences major developmental limitations, usually not being aware either of the parent's emotions or of the effects of his or her indifferent or aggressive behavior ${ }^{18}$;

i) self-love, when "this type of love is to some extent not reciprocated, the same as the former, but here, it is limited to the parent and does not unite the parent with the child"19. Parents with self love are so focused on their own problems that, in a relationship with a child, they only notice him or herself. A child may feel to be only the background for emotions, thoughts, behaviors of the parent;

j) wise love, that makes it possible to love a child, be sensitive to his or her needs and at the same time, as Małgorzata Kościelska writes, "thinking with the heart" enables the parent to feel important, to achieve the values that matter for him or her and fulfil everyday life with other content than the disability of a child and the related limitations ${ }^{20}$. A child bestowed with wise love has a chance to grow up in a family, where every member is important and has the right for his or her subjectivity.

k) love that makes happy, usually developed at the end of a long road to accepting a child's uniqueness. Such love enables parents to "live a life without a feeling of pain and failure, replaced by the dominant feeling of acceptance for the child as he or she is, for oneself an for the family, with the ability to draw satisfaction from all the events of everyday life" 21 . Such

\footnotetext{
18 Ibidem, p. 62-63.

19 Ibidem, p. 63.

20 Cf ibidem, p. 63.

21 Ibidem, p. 65.
} 
love - despite, or maybe thanks to the child's disability - enables parents to feel that they live a good and happy life. Such love should be wished to parents and children, as it makes the life of the whole family normal and enables a sense of a high quality of life.

The research shows that persons with disabilities experience the love of their parents. They experienced it in childhood and they experience it in their adult life. Interestingly, those persons often perceive changes taking place over the years in the attitudes and the feelings of their parents and the way they show them. These changes take the following directions:

a) from unconditional to conditional love:

Mum used to love me just because I was there and now, I feel that I am loved for being... such and such, like my mum expects me to be (...). She loves me, but I think she shows that love more when, in her opinion, I deserve it more. (...) Because I have good grades at school or dress properly for an occasion, because I do not cause problems, like my cousin does who had a child before she graduated from school22;

b) from love expressed directly to restrained, somewhat concealed love:

It is normal that you hug and kiss a small child, that you tell that you love him or her, but as the child becomes older, the feelings are no longer so openly shown. Such was the case in my house, too. I remember that, when I was a child, I could not "escape" from my parents' love, and as a teenager, I was even ashamed before my girl friends because of such manifestations of love: "give me a good-bye kiss (...) mummy lovers you, have a good day". Now, that I am 23 years old and no longer sit on my parents' knees or kiss them goodbye, or hug them, or tell them "I love you" (...), I need to know that that love is still there. They love me..., if they didn't, they

${ }^{22}$ All the quotations come from interviews, cf. footnote 10. 
wouldn't be like that for me (...) wonderful, understanding, giving them all to myself, their little daughter. I love them too, just don't tell them, because such things do not need telling. I know and they know ${ }^{23}$;

c) from love full of control to trusting love that accepts independent choices:

Mum's love was always and everywhere, so possessive, (...) I could feel that for my sake, mum will never stop being so overprotective. (...) I know that every loving parent cares, but my mum was always worried about me, because not only was I her only child but I also had epilepsy. She would always be near me. (...) Now, I am grown up and mum... she has matured to understand that a child grows up and becomes independent. We have tamed my illness and my mum feels more comfortable. She knows I can cope, she knows I am responsible, so her own control has loosened, I feel I can breathe, but I also know that I can always tell her about my problem and I will not be left alone (...). I would like to be a mother like her one day24;

d) from love that is desired to love that is a burden:

I am grateful to my family for taking such good care of me, and even for taking many of my duties off me. I could not cope on my own. (...) The illness came so suddenly, I was terrified, if it was not for my family... (...) sometimes their care is a nuisance, because I'm just ill, not dying 25 (response of an adult man suffering from diabetes and surrounded by a big and supportive family); "I look at my family and I see people who love me. It is important for me, but (...) my parents make such a fuss about me (...), I hate it when people lament over me, I don't like it when want to help me even if I don't need it (...). It was only when I came here that I felt

\section{${ }^{23}$ Ibidem.}

${ }^{24}$ Ibidem; Cf J. Lipińska-Lokś, Koleżeństwo i przyjaźn w doświadczeniach osób z niepetnosprawnościa, "Niepełnosprawność. Dyskursy Pedagogiki Specjalnej” 2015, no. 20, p. 65 .

${ }^{25}$ Ibidem. 
alive again ${ }^{26}$ (response of a student who, having overprotective parents, felt suppressed by them and felt she was free only when she started studying away from home).

However, the respondents always emphasize that their parents' love is honest and unselfish, and they may be certain that, for as long as their parents are around, their closeness will be natural.

However, there are persons with disabilities who were not/are not certain of the true love of their parents. Does a parent - a mother love a child, if she rejects him or her, abandons emotionally or gives him or her away, because she cannot, she will not live her life with the burden of disability? Does someone who is explicitly or implicitly ashamed of his or her child, love that child? It is not quite rare that a child hears: I cannot look at you, because all I see are the bad things that happened to $m e^{27}$ (a girl with cerebral palsy; difficult delivery, lack of acceptance by the family, quoted her mother). When the aunt comes, do not talk too much with her, only answer "yes" or "no", she does not need to know about your problems ${ }^{28}$ - z 25-year-old man with intellectual disability remembers what her mother once told him. The donkeywork again, to work, from home, from this $\operatorname{cosmos}^{29}$ - said by the father of a person with hearing impairment, serious visual impairment and chronically ill. Such parents, even if they look after their not fully abled children - even the adults ones, do it probably with a sense of duty, because this is the right thing to do, and in order to heave clean conscience. They do their duties routinely, without kindness and warmth. Perhaps it is the consequence of many years of daily hardships, or of lack of acceptance for a child with disability and for oneself as the parent of such a child. It is a difficult experience in the life of both a parent and a child, who is not indifferent to difficult situations in the family home and to distorted bonds with the closest persons - the parents. Sometimes, relations with parents

\footnotetext{
26 Ibidem.

27 Ibidem.

28 Ibidem.

${ }^{29}$ Ibidem.
} 
cast a shadow on the relations with other people, established either in childhood or in adult life. Relations with parents, as the respondents suggest, become a road sign for relations with other people ${ }^{30}$ and are a manifestation of esteem and respect for another person ${ }^{31}$.

\section{Love in the life of adult persons with disabilities}

A human being has the natural need for relations with other people, for establishing close bonds with them. He or she desires, through contacts with others, to satisfy their psychological needs: of belonging, acceptance, esteem and closeness. Affiliative relations of friendship make it possible to satisfy such important human needs. Undoubtedly, however, in adult life, love-based relations are particularly important. And although "love is hard to define, love has more than one name..."32, its appearance ennobles human existence and makes it possible to express one's feelings, desires and emotions, and to achieve the fullness of self-realization, and often constitutes the core sense and goal of life ${ }^{33}$.

The essence of love is not only to take from its resources, but also to give something to the loved person. After all, love is "a deep feeling, driven by passion, friendship or attachment, making the partners to care for each other, to get rid of one's egoism and actions that cause moral damage" 34 . Both parties achieve certain advantages on love. It is worth noting that "life together stimulates a sense of happiness (...) married persons take their strength from the close,

\section{${ }^{30}$ Ibidem.}

${ }^{31}$ Cf A.P. Sperling, Psychologia, Wydawnictwo Zysk i S-ka, Poznań 1995, p. 181.

32 W. Żarski, B. Staniów, Wstęp, [in:] Miłość niejedno ma imię. Studium monograficzne, ed. W. Żarski, B. Staniów, Państwowa Wyższa Szkoła Zawodowa w Koszalinie, Koszalin 2011, p. 5.

${ }^{33}$ Cf ibidem

${ }^{34}$ W. Szewczuk, Stownik psychologiczny, Wiedza Powszechna, Warszawa 1998, p. 250. 
intimate and supportive relationship with the partner and less often experience loneliness. (...) life in a union with another person is a chance for them to assume the additional roles of a husband or wife, mother or father, the fulfilment of which may be an important source of self-esteem" 35 .

The latter quotation becomes particularly significant with respect to persons with disabilities, who, experiencing their disabilities, are often exposed to suffering their negative consequences, namely:

a) being treated like children despite reaching formal and actual maturity, adulthood,

b) not being allowed (usually by parents who are overprotective or simple take care of their child) to be independent in adult life,

c) treating the adulthood (sexuality) of persons with disabilities as a taboo or at least difficult topic,

d) isolating, backing away from social contacts due to feeling like someone different - not full abled, which means worse, may result in low self-esteem,

e) social exclusion as a result of negative social attitudes.

The results of the research confirm that the adulthood of the respondents is regarded, both by themselves and their communities, most often from the perspective of their disabilities:

Whenever I think about something, I always confront it with my disability, whether I can, whether I will manage, what will people say?36 what the girl said fully illustrates the situation. Another respondent sais: I accept myself, I accept my otherness, but sometimes, it hurts me that I lose something because of my disability, that it limits me (...) mainly physically, but also mentally, because I'm afraid of something, terrified of something, ashamed (...). Yes, I often wonder p. 567.

35 D.G. Myers, Psychologia społeczna, Wydawnictwo Zysk i S-ka, Poznań 2003,

36 All the quotations come from interviews. 
what my life would be like without disability (...). I give up, because I shouldn't, because, being handicapped, I cannot, I won't make it (...). I give in to it, because I think I am too weak to fight not only with my own weaknesses, but also with so-called social opinion (...). Apparently, I am so free, but I depend on the opinion of my parents, friends... strangers on the street (...). They comment on my disability and it is enough for me, I don't want them to have more reasons to talk about ${ }^{37}$.

Research shows that persons with disabilities are aware of the importance of relations with other persons, of the feelings they have for others and others have for them:

Everyone needs someone to talk to (...), to tell about one's sorrows, to cry, (...) and it is better to be joyful in a company (...) it is so normal: to have a soul mate, someone close $e^{38}$.

The research also shows the great desire of the respondents to love and be loved. They often say:

At one point in life, the love of the parents, siblings, grandparents is no longer enough, you want someone else to love you, too (...). I want to experience another kind of love, I want to make sure that I can love someone who is not my family - first, a stranger, then the closest person in the world39; I would give everything to experience real love 40 ; The day I met my wife was the happiest day in my life, and that happiness later exploded when my children were born. (...) before, I did not even dream I would have all this (...) and live like ... a person ${ }^{41}$.

Analysis of the content of the interviews showed four images of love in the lives of persons with disabilities.

\footnotetext{
37 Ibidem.

38 Ibidem.

${ }^{39}$ Ibidem.

40 Ibidem.

${ }^{41}$ Ibidem.
} 
The first image, where love, experiencing it and waiting for it, is a natural stage in the development of every human being, regardless of their health and degree of ability. The most characteristic of the interview responses are: Everyone has the right to lovee2; There's a nut for every bolt - funny, isn't it? I believe there is my other half somewhere out there, someone who will see a woman, not a cripple in me43; "It's not for me yet (...) I am too young. Young people are not responsible. One day certainly (having a family and children), when I'm ready. I am not mature enough for it, yet" 44 . The respondents treat love as something embedded in human existence. For some, it comes sooner, for others later, but loving is just a matter of time ${ }^{45}$. One will be found by a prince on white horse46, others will meet someone one $d a y^{47}$. It is worth noting here, how important it is for the respondents to be perceived by others in the categories of a person, rather than a person with disability who perhaps should be love out of goodness, of pity. It is also worth noting the attitude of the respondents to a relationship with another person, mainly, they speak of readiness, maturity and responsibility.

The other image in fact does not contain love, but it is full of loneliness and suffering, a sense of loss - initially, which later, with the passage of time, transforms into acceptance of the existing condition, as it is normal that love does not happen to the disabled48; Love exists in the reality of young, beautiful and healthy persons 49 ; "Have someone to hug to. A man who will... support, respect, love, (...) but, being disabled, I can only dream about it" ${ }^{\prime 50}$. In few of the re-

42 Ibidem.

${ }^{43}$ Ibidem.

${ }^{44}$ B. Kałużna, J. Lipińska-Lokś, Aspiracje i plany życiowe (nie)petnosprawnych zielonogórzanek, "Niepełnosprawność - zagadnienia, problemy, rozwiązania” 2016, no. 1, p. 69.

${ }^{45}$ All the quotations come from interviews.

${ }^{46}$ Ibidem.

${ }^{47}$ Ibidem.

48 Ibidem.

${ }^{49}$ Ibidem.

${ }^{50}$ B. Kałużna, J. Lipińska-Lokś, op. cit., p. 72. 
sponses, love is perceived as something real and attainable, but, it should be noted that then, respondents perceive that love as a substitute of the love that is available to abled persons, depreciating either their own value, or the value of the person who will love (...) and will be (...) loved51; I cannot hope for much, maybe someone ill like will take interest in me (...). I only have a chance to meet someone like me, because this is the only kind of friends I have. (...) I wouldn't dare to speak to a healthy boy ${ }^{52}$. Persons with disabilities often feel responsible for not experiencing love in their lives: I do not want to be a burden to anyone. And I even don't know if I can love at all, though perhaps... after all, I love the sea, birds singing, flame in the fireplace ${ }^{53}$. It is worth pondering here on what the respondent said, who, on the one hand, perceives love to a person with disability as a burden but, on the other hand, is doubtful about the quality of love of a person with disability, whether, not being fully abled, she can give a valuable feeling to another person, whether she can love another person. Accepting herself and her disability, she at one point answers her own questions: after all, she feels something that she identifies as love in contact with the world.

Another, third image shows a great desire for love, but is also full of fear of it. The respondents crave for love, they want to love and be loved, however, they are often hindered from experiencing love by huge fear, at the bottom of which lies thinking about their disability and its consequences. The respondents are afraid of their reaction should they meet a person who would love them: I' $m$ afraid I would run away from love, because I don't know what it's like when people love each other ${ }^{54}$. They have certain fears about the intentions of the persons who would assure them of true love: "I would like first to achieve something, so that that person would be interested in me for other reasons, not only to help me or feel sorry for me" $\mathrm{m}^{\prime 5}$. Fear of

\footnotetext{
${ }^{51}$ All the quotations come from interviews.

52 Ibidem.

53 Ibidem.

${ }^{54}$ Ibidem.

${ }^{55}$ B. Kałużna, J. Lipińska-Lokś, op. cit., p. 69.
} 
love appears also when persons with disabilities think about the reactions of other persons: To love is to devote oneself to another person, and if that person were unhappy, to not allow that, even if that would make us unhappy (...). We can be buddies or even friends, but if we fell in love, I don't know if my parents would take it with joy (...). It's good as it is $(\ldots)^{56}$. It is also of no little significance, thinking about "the fruits of love", of the intimate relationship between two adult persons. Having children is huge responsibility and a major changer in life, perhaps a child could inherit the disability of a parent - such perception of the parental love as a natural consequence of the love of spouses may be a source of fear of having close, intimate relations with another person.

And the last, fourth image, very different from the former. Here, the desire for love is so great that nothing else matters. It is important to love and be loved, to satisfy the natural human need to feel what "normal people" feel, to experience love regardless of the consequences. Characteristic of such love is the response of a young woman: "(..) with a classmate (...), it was in high school (..), he was kind, I liked it when he always listened patiently to what I said, he smiled and helped me when there was something I did not understand at school, (...) he wanted to, (...) I didn't want to refuse, he was good, like no one else at school, (...) he understood me, we could always talk, his parents were also divorced, my father left, my mother had a new partner, and she was no good to talk to about things, (...) long, not long, does it matter? he found a better girl not hard of hearing like myself, that you have to try hard to understand (...) no, I don't feel used, I also wanted, it was good when we went out together" 57 . This response not only shows "love above all else", but also the drama of otherness and loneliness and the huge, almost blind craving for love and normality. This is a one step away

${ }^{56}$ All the quotations come from interviews; cf J. Lipińska-Lokś, Zachowania ryzykowne młodzieży z niepetnosprawnościa, „Interdyscyplinarne Konteksty Pedagogiki Specjalnej" 2014, no. 7, p. 22-23.

${ }^{57}$ J. Lipińska-Lokś, Zachowania..., p. 22-23. 
from abuse and violence with respect to a person with disability. Such persons may become victims of mistreatment. This situation is, undoubtedly, often stimulated by social isolation of persons with disabilities, the abovementioned non-fulfilment of needs (for safety, belonging, acceptance) and a huge hunger for feelings and closeness, and fear of rejection. It is very easy to hurt a person, who, due to his or her limitations (mainly intellectual) does not have a sense of the impropriety of violence. If we add to this the typical social perception of persons with disabilities as less worthy and unable to feel pain, fear or humiliation, their mistreatment actually appears to be a natural phenomenon ${ }^{58}$. Even persons with disabilities, who do not fully accept themselves and their disability, feeling guilt and shame, get used to mistreatment and often think they deserve it. Living in a circle of mistreatment, paradoxically they search for something positive in it, they believe that this way, they experience a substitute of happiness: He was interested in me, I was important for him then (...). I gave him joy, (...) I felt happy ${ }^{59}$.

In a reflection on adulthood, one must not forget about the motherhood, fatherhood, parenthood of persons with disabilities, even though this is one of the more difficult issues in social discourse and in the reality of persons, particularly women, with disabilities. Aleksandra Maciarz claimed that:

the motherhood of an ill and disabled person is difficult because of her limited or even lack of ability to take an effort and independently perform physical tasks, or make decisions and solve the problems of everyday life. (...) however, only some women who are chronically ill or disabled resign from motherhood. Most of them desire to meet their needs concerning family life and motherhood, they get married and have children. Usually, these women need help in their motherly du-

58 K. Mrugalska, M. Zima, Doświadczanie przemocy przez osoby niepetnosprawne, "Ręce sa do przytulania", Biuletyn RPO Konferencja Rzecznika Praw Obywatelskich, Warszawa 2010.

59 All the quotations come from interviews. 
ties and with overcoming the difficulties associated with their limitations caused by illness and disability ${ }^{60}$.

The theme of having offspring was mentioned in many interviews and, the same as love, the desire to experience it, to have a husband, wife, partner were presented in many different ways, this particular issue has many different shades, too. However, in most responses one could sense a great desire to have a child, a dream to become a mother, a father, a parent. At the same time, the respondents are afraid that this dream will never come true: I had a dream once - I went fishing with my son, I taught him to catch fish then, I woke up (...) I don't have a son and probably never will have - who with, if no girl even wants to look at me (...), how would I handle fishing with a kid if I need help myself61. A young woman says: I have a dream something that is so natural for others that they even don't think or talk about it, it just happens to then and I dream and will probably always only dream (...). I will say it very quietly: I would like to be a mum (...). Do you think it's possible? That someone like me could have a husband, a child?62.

Interestingly, the respondents also fear that their dream of having offspring could come true, because they fear they might give live to a child with disability. A sense of guilt for the disability of a child, a sense of remorse for hurting an innocent creature is so great that it constitutes a barrier that - they intuitively feel - cannot be overcome.

In a situation when the arrival of a child was just a coincidence, I did not plan it but it just happened ${ }^{63}$ or if a child was born before a parent became disabled - there is another reflection, namely: will I cope as a mother? (...), who will help me, if I won't be able to take care of

60 A. Maciarz, Macierzyństwo w kontekście zmian społecznych, Wydawnictwo Akademickie "Żak”, Warszawa 2004, p. 31-32.

61 All the quotations come from interviews.

62 Ibidem.

63 Ibidem. 
the child?64. Parents are also doubtful about their children's love and acceptance of them - ill and disabled parents whose children are healthy and abled: I hope my son will love me like I love him (...). I love him more than my life and always will!65. In the young mother's words, one can sense love and faith that her unconditional love will be reciprocated, which will compensate for all her misfortune in life and make hopeful about the future. This is what we should wish her and persons like her, who, despite disability, or maybe thanks to disability, crave to live and make their dreams and desires come true. It should also be hoped that those persons will be surrounded by supportive persons in situations that will be difficult for them and beyond their ability to cope on their own with adversities and unkindness of people who find it very difficult to acknowledge the right of persons with disabilities to happiness.

\section{Conclusions}

The research undoubtedly proves that there is the theme of love in the experiences of persons with disabilities. This theme reappears practically throughout their entire life. As children, they experience the love of their parents, the types of which are so many and so diversified as there are parents' attitudes to children. And as different the parental attitudes are, as diversified are the effects of the respective variations of love on the functioning of children and their present and future lives. In the adult life of persons with disabilities, alongside the still present parental love, there appears also the sensual love between partners. This is the natural course of events in human life, but, in the case of the biography of persons with disabilities, its existence is not at all that evident. Adults with disabilities can often only dream about love or abandon that feeling in a relationship with another person, and replace it with a feeling to the

\footnotetext{
64 Ibidem.

65 Ibidem.
} 
world and life as such, or create a philosophy of life, where there is no room for such love. The same is with the love of an adult person with disability as a mother or a father. Natural developmental limitations are often a real obstacle to becoming a mother or a father. More often, however, a person with disability has an internal, mental blockade that stops him or her from assuming the role of a parent. Of no little significance are also social stereotypes, which put into question the procreative and parental success of persons with disabilities.

It should be noted that, in many cases, persons with disabilities themselves cannot, do not know how to or do not want to acknowledge the responsibility of a parent, a father or a mother. They cannot fully recognize their abilities to meet this challenge. This, indeed, may hinder making an informed decision on having a child, becoming a parent. An attempt to help recognize one's own parental possibilities and become aware of one's own limitations, and make a decision on becoming or not becoming a parent more informed are educational projects ${ }^{66}$ with the use of toddler simulators, where conditions are created that enable persons with disabilities (mostly intellectual)

to experience parenthood at least to some extent. (...) a toddler simulator is undeniably a tool that teaches. It teaches specific skills, such as changing the diaper, feeding, lulling, holding in arms. It familiarizes one with the phenomenon of adulthood, it shows what it is like and

${ }^{66}$ An example of such project is and educational program implemented under the academic supervision of Zbigniew Izdebski: "Be responsible - bringing up a person to responsibility and partnership in family" (A. Gonera, Symulatory niemowlęcia a uczenie się rodzicielstwa, "Niepełnosprawność. Dyskursy Pedagogiki Specjalnej” 2015, no. 20, p. 191; cf K. Wąż, Realizacja programu, [in:] Bądź odpowiedzialny. Wychowanie do odpowiedzialności i partnerstwa w rodzinie. Opis programu edukacyjnego i jego realizacji, ed. K. Wąż, Oficyna Wydawnicza Uniwersytetu Zielonogórskiego, Zielona Góra 2008. The project inspired the authors (e.g. Katarzyna Karczewska, Izabela Fornalik) of another project - "Taming the adulthood", the purpose of which was to enable persons with intellectual disabilities to experience, at least to some extent, the adulthood, parenthood (A. Gonera, op. cit., p. 190-199) 
what duties it is associated with. It should be remembered, however, that there is more to parenthood that just a set of competencies, it is a type of a unique bond that can exist only between two persons ${ }^{67}$.

One cannot become a parent only for a moment, try loving and being loved by a child and then, if he or she does not like it or becomes bored with it, or if it is too difficult, stop loving.

Relevant to the topic of this article is also the problem of feelings as such, of love in today's reality. A human being, rushing through life, experiences emotions and feelings. Some of them are between colleagues or friends, others are called love. Unfortunately, very often a colleague is a rival to achieving e.g. professional success. Someone, whom we called a friend, let us down when we needed the support of a real friend 68 . And love...? Well, let us hope we will find it one day and, indeed, it will prove to be love, not infatuation, not mutual interest, not an illusion of closeness with another person. Love is such a natural human need, so why is it so difficult to find? Or, perhaps, we pass it by indifferently only too often, or we do not recognize it in what we experience?

\section{Bibliography}

Bakiera L., Stelter Ż., Leksykon psychologii rozwoju człowieka, Dyfin SA, Warszawa 2011.

Dunaj B., Stownik wspótczesnego języka polskiego, Wydawnictwo WILGA, Warszawa 1996.

Fragments of unpublished interviews with persons with disabilities as part of the author's own research and diploma dissertations supervised by the author.

Gonera A., Symulatory niemowlęcia a uczenie się rodzicielstwa, „Niepełnosprawność. Dyskursy Pedagogiki Specjalnej" 2015, no. 20, 190-200.

Kałużna B., Lipińska-Lokś J., Aspiracje i plany życiowe (nie)petnosprawnych zielonogórzanek, „Niepełnosprawność - zagadnienia, problemy, rozwiązania” 2016, no. 1, p. $60-89$.

67 A. Gonera, op. cit., p. 191, 199.

${ }^{6}$ Cf J. Lipińska-Lokś, Koleżeństwo..., p. 57-69. 
Kościelska M., Oblicza upośledzenia, Wydawnictwo Naukowe PWN, Warszawa 1995. Lipińska-Lokś J., Zachowania ryzykowne młodzieży z niepetnosprawnościa, „Interdyscyplinarne Konteksty Pedagogiki Specjalnej" 2014, no. 7, p. 9-25.

Lipińska-Lokś J., Koleżeństwo i przyjaźn w doświadczeniach osób z niepetnosprawnościa, „Niepełnosprawność. Dyskursy Pedagogiki Specjalnej” 2015, no. 20, p. 57-69.

Maciarz A., Macierzyństwo w kontekście zmian społecznych, Wydawnictwo Akademickie "Żak”, Warszawa 2004.

Mrugalska K., Zima M., Doświadczanie przemocy przez osoby niepetnosprawne, „Ręce są do przytulania", Biuletyn RPO Konferencja Rzecznika Praw Obywatelskich, Warszawa 2010.

Myers D.G., Psychologia społeczna, Wydawnictwo Zysk i S-ka, Poznań 2003.

Reber A.S., Stownik psychologii, Wydawnictwo Naukowe SCHOLAR, Warszawa 2002.

Sperling A.P., Psychologia, Wydawnictwo Zysk i S-ka, Poznań 1995.

Szewczuk W., Stownik psychologiczny, Wiedza Powszechna, Warszawa 1979.

Szewczuk W., Encyklopedia psychologii, Fundacja Innowacja, Warszawa 1998.

Szymborska W., Gawę̨da o miłości Ziemi Ojczystej, [in:] Strofy o Ojczyźnie. Antologia, S.R. Dobrowolski (wybór), Państwowe Wydawnictwo „Iskry”, Warszawa 1978.

Św. Paweł, Pierwszy List do Koryntian, 1 Kor 13, BIBLIA to jest PISMO ŚWIĘTE STAREGO I NOWEGO TESTAMENTU, Komisja Przekładu Pisma Świętego (przekład), Brytyjskie i Zagraniczne Towarzystwo Biblijne, Warszawa 1977.

Wąż K., Realizacja programu, [in:] Bądź odpowiedzialny. Wychowanie do odpowiedzialności i partnerstwa $w$ rodzinie. Opis programu edukacyjnego i jego realizacji, ed. K. Wąż, Oficyna Wydawnicza Uniwersytetu Zielonogórskiego, Zielona Góra 2008.

Żarski W., Staniów B., Wstęp, [in:] Miłość niejedno ma imię. Studium monograficzne, ed. W. Żarski, B. Staniów, Państwowa Wyższa Szkoła Zawodowa w Koszalinie, Koszalin 2011. 